\title{
A double-blind trial of salmefamol, a new bronchodilator
}

\author{
D. BAINBRIDGE \\ M.R.C.P.* \\ G. J. R. MCHARDY \\ F.R.C.P.E. \\ MARgaret V. HoARe \\ C. H. DASH \\ M.Sc. \\ M.B., Ch.B., D.Obst.R.C.O.G.

\begin{abstract}
Departments of Respiratory Diseases and Statistics, University of Edinburgh and
Clinical Research Unit, Medical Department, Glaxo Laboratories Ltd., Greenford, Middlesex
\end{abstract}

\begin{abstract}
Summary
Salmefamol is a new sympathomimetic drug with predominantly $\beta_{2}$ actions. In a double-blind trial in a group of twenty-four patients with airway obstruction, we have compared the effect of $100 \mu \mathrm{g}$ of salmefamol given by metered aerosol with that of a placebo aerosol. In the same patients we have also compared the aerosols with subcutaneous adrenaline and subcutaneous atropine, the sequence of treatments being determined by a latin square design.

At all times salmefamol had a significantly greater bronchodilator effect than the placebo. Although the effects of atropine and adrenaline were greater at the earlier times of measurement, that of salmefamol was greater at $4 \mathrm{hr}$.
\end{abstract}

\section{Introduction}

Sympathomimetics are widely prescribed for the treatment of reversible airway obstruction. They can be carried in aerosol form ready for instant use, and they produce their greatest effect within a few minutes of inhalation. Lands et al. (1967) distinguished between the cardiac stimulant effect $\left(\beta_{1}\right)$ and the bronchodilator and vasodilator effects $\left(\beta_{2}\right)$ of sympathomimetic drugs. This encouraged the search for sympathomimetics whose action on the airway would be greater than on the heart, achieving bronchodilation with minimal cardiac stimulation. A number of drugs producing selective $\beta_{2}$ effect have since been introduced, including salbutamol (Cullum et al., 1969; Kennedy and Simpson, 1969; ChooKang, Simpson and Grant, 1969). Salmefamol, AH 3923, is a close chemical relative of salbutamol, AH 3365 (Fig. 1), with similar specificity in laboratory experiments (Hartley et al., 1968). It has been shown in animal experiments to have twice the

\footnotetext{
* Present address: Park Hospital, Moorside Road, Davyhulme, Manchester M31 3SL.

Correspondence: Dr C. H. Dash, Clinical Research Unit, Medical Department, Glaxo Laboratories Ltd, Greenford, Middlesex.
}

bronchodilator effect of salbutamol when they are compared on a weight for weight basis, while the acute oral $\mathrm{LD}_{50}$ in mice and rats is over $1 \mathrm{~g} / \mathrm{kg}$ (Brittain and Poynter, 1970). This new substance therefore seems likely to be a useful therapeutic agent. Since the work of Crompton (1968) we have investigated the reversibility of airway obstruction by comparing control values of $\mathrm{FEV}_{1}$ and $\mathrm{FVC}$ with those obtained after subcutaneous injection of adrenaline on the first day and subcutaneous injection of atropine on the next. The patients in this study had all been referred from the wards of the University Department of Respiratory Diseases for such an assessment. We therefore compared the effects of an aerosol of salmefamol and a placebo, in a double-blind manner, with the two standard bronchodilators employing a within-patient study.

\section{Subjects}

Twenty-four patients participated in the trial. Their age, sex and other relevant details are shown in Table 1. All of them were studied while in-patients of the University Department of Respiratory Diseases. Every patient had previous spirometric evidence of airway obstruction, as shown by a reduction in the ratio of forced expiratory volume in one second $\left(F E V_{1}\right)$ to forced vital capacity (FVC). The trial was conducted over a period of 5 days, during which no routine bronchodilator therapy was given. Nine of the patients had been taking prednisolone before admission to hospital; they remained on their usual dose during the period of the trial. The twenty-four patients all agreed to take part after the nature and aim of the study had been explained to them.

The pre-treatment FEV 1 and FVC of the patients covered a wide range, for example, the values for patient 22 were close to her predicted levels, while those of patient 16 were very low. Analysis of covariance was used to allow for these differences in the pre-treatment values by adjusting the increases 
<smiles>CC(C)(C)NCC(O)c1ccc(O)c(CO)c1</smiles><smiles>COc1ccc(CC(C)NCC(O)c2ccc(O)c(CO)c2)cc1</smiles>

Fig. 1. Structural formulae of (a) salbutamol and (b) salmefamol.

TABLE 1. Details of patients studied

\begin{tabular}{|c|c|c|c|c|c|c|c|}
\hline \multirow[b]{2}{*}{ Patient } & \multirow[b]{2}{*}{ Sex } & \multirow[b]{2}{*}{ Age } & \multicolumn{2}{|c|}{ First pre-treatment } & \multicolumn{2}{|c|}{ Predicted* } & \multirow[b]{2}{*}{$\begin{array}{l}\text { Whether on } \\
\text { corticosteroids }\end{array}$} \\
\hline & & & $\begin{array}{c}\text { FEV }_{1} \\
\text { (ml BTPS) }\end{array}$ & $\begin{array}{c}\text { FVC } \\
\text { (ml BTPS) }\end{array}$ & $\begin{array}{c}\text { FEV }_{1} \\
\text { (ml BTPS) }\end{array}$ & $\begin{array}{c}\text { FVC } \\
\text { (ml BTPS) }\end{array}$ & \\
\hline 1 & $\mathbf{M}$ & 65 & 800 & 1925 & 2300 & 3200 & No \\
\hline 2 & $\mathbf{M}$ & 55 & 870 & 2600 & 2780 & 3800 & No \\
\hline 3 & $\mathbf{F}$ & 51 & 1370 & 2150 & 2300 & 2700 & Yes \\
\hline 4 & $\mathbf{F}$ & 34 & 1900 & 3750 & 2800 & 3300 & No \\
\hline 5 & $\mathbf{F}$ & 15 & 1900 & 2650 & 2750 & 3050 & No \\
\hline 6 & $\mathbf{F}$ & 20 & 1750 & 2800 & 2820 & 3350 & No \\
\hline 7 & $\mathbf{F}$ & 62 & 590 & 1720 & 2050 & 2500 & Yes \\
\hline 8 & $\mathbf{M}$ & 73 & 1230 & 2710 & 2100 & 3150 & Yes \\
\hline 9 & $\mathbf{F}$ & 77 & 920 & 1330 & 1300 & 1500 & No \\
\hline 10 & $\mathbf{F}$ & 71 & 500 & 1400 & 1900 & 2350 & No \\
\hline 11 & $\mathbf{M}$ & 68 & 900 & 1950 & 2950 & 4250 & No \\
\hline 12 & $\mathbf{M}$ & 58 & 1520 & 3200 & 2650 & 3550 & No \\
\hline 13 & $\mathbf{M}$ & 62 & 1890 & 3930 & 2800 & 2970 & Yes \\
\hline 14 & M & 18 & 2250 & 3050 & 3810 & 4400 & No \\
\hline 15 & $\mathbf{M}$ & 17 & 2350 & 4400 & 3450 & 3800 & Yes \\
\hline 16 & M & 60 & 470 & 2720 & 2520 & 3600 & No \\
\hline 17 & F & 75 & 1120 & 1460 & 1500 & 1800 & Yes \\
\hline 18 & M & 67 & 580 & 1840 & 2220 & 3100 & Yes \\
\hline 19 & F & 53 & 760 & 1640 & 2000 & 2400 & Yes \\
\hline 20 & $\mathbf{M}$ & 54 & 2350 & 4000 & 3000 & 4000 & No \\
\hline 21 & $\mathbf{M}$ & 73 & 1000 & 2000 & 2400 & 3700 & No \\
\hline 22 & $\mathbf{F}$ & 18 & 3100 & 4200 & 3300 & 3800 & Yes \\
\hline 23 & $\mathbf{M}$ & 41 & 1800 & 3525 & 3200 & 4000 & No \\
\hline 24 & $\mathbf{M}$ & 63 & 900 & 1500 & 2600 & 3550 & No \\
\hline
\end{tabular}

* Predicted values from Cotes (1968).

in $\mathrm{FEV}_{1}$ and $\mathrm{FVC}$ following treatment (Armitage, 1971a).

\section{Procedure}

$\mathrm{FEV}_{1}$ and FVC were measured using an electronically timed spirometer (McKerrow, McDermott and Gilson, 1960). All measurements were made by experienced laboratory technicians or by one of us (D.B.). The same person made all the measurements on a given patient in all but two instances. The highest value of three technically satisfactory attempts for each variable was used for the statistical analysis (Freedman and Prowse, 1966).

The treatments consisted of (1) placebo aerosol (propellants only); (2) salmefamol aerosol (50 $\mu \mathrm{g}$ per metered dose) [(1) and (2) by inhalation]; (3) adrenaline $0.5 \mathrm{mg}$; (4) atropine $0.6 \mathrm{mg}$ [(3) and (4) by subcutaneous injection].

Salmefamol and the placebo were administered from identical aerosol canisters, each marked with a number code whose key was unknown to the investigators. The canister was shaken and dis- $o r$ charged once into the air. One puff of aerosol was $N$ then administered by a technician whilst the patient $\underset{\omega}{N}$ slowly inhaled from functional residual capacity. The patient continued breathing in until total lung 0 capacity was reached and then, after a short pause, $\mathbb{D}$ exhaled normally. A second puff was administered $\stackrel{?}{?}$ in the same way about one minute later. This gave a 0 total dose of $100 \mu \mathrm{g}$ of salmefamol. The atropine 
and the adrenaline were given by subcutaneous injection. The adrenaline injection was given slowly, taking up to $2 \mathrm{~min}$. It was therefore not possible to use a double-blind procedure for these drugs. Each treatment was administered by 10 a.m. on consecutive mornings and was preceded by the initial measurements of the $\mathrm{FEV}_{1}$ and FVC. The measurements were repeated $20,80,120$ and 240 min after the treatment. On the fifth day no treatment was given but a final measurement of $\mathrm{FEV}_{1}$ and FVC was made at 10 a.m.

All patients received each of the four treatments during the first 4 days of the trial. The order of treatments was determined by a latin square design suggested by Professor D. J. Finney. Each subgroup of four patients formed a $4 \times 4$ latin square and so all twenty-four of the possible sequences of the four treatments were used. With such a design, each patient acts as his own control, thus improving the precision with which effects of treatment are estimated. Any effect of the sequence of treatments can also be calculated and allowance made for this in the statistical analysis of comparisons (Armitage, 1971b).

\section{Results}

The results below are presented in terms of the grouped values. Results of individual measurements on all patients can be obtained from the authors. The value of such detailed information has been stressed by Oldham and Hughes (1972).

The changes in $\mathrm{FEV}_{1}$ resulting from the different treatments, including the placebo, at the four different times after the dose are shown in Table 2. The values are expressed as the mean increases in $\mathrm{FEV}_{1}$ over the pre-treatment values. The time course of the responses to the drugs is shown in Fig. 2. Salmefamol can be seen to produce an effect significantly greater than that of the placebo at all times up to $240 \mathrm{~min}$, the total duration of observation $(P<0.05)$.

TABle 2. Mean increases in $\mathrm{FEV}_{1}$ (ml BTPS) over pretreatment values

\begin{tabular}{lrrrr}
\hline & \multicolumn{4}{c}{ Time after treatment (min) } \\
\cline { 2 - 5 } \multicolumn{1}{c}{ Drug } & 20 & 80 & 120 & 240 \\
\hline Placebo aerosol & 33 & 51 & 77 & 6 \\
Salmefamol aerosol & 216 & 228 & 222 & 215 \\
Adrenaline s.c. & 281 & 292 & 318 & 128 \\
Atropine s.c. & 311 & 372 & 347 & 97 \\
$\begin{array}{l}\text { Standard error of the } \\
\text { difference between }\end{array}$ & & & & \\
two drug means & $51 \cdot 2$ & $53 \cdot 4$ & 60.0 & 56.0 \\
\hline
\end{tabular}

The difference between two drug means is significant at (approximately) the $5 \%$ level when the observed difference between the means is greater than twice the standard error of the difference.

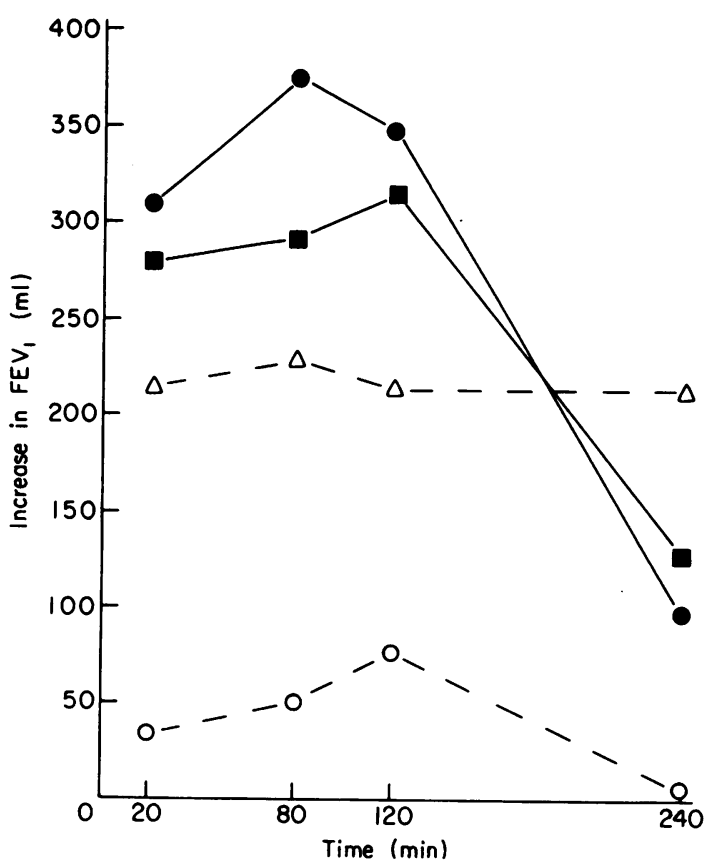

Fig. 2. Mean changes in $\mathrm{FEV}_{1}$ (ml BTPS) resulting from $\sigma$ the different treatments: atropine (C), salmefamol $(\triangle--\triangle)$, adrenaline $(\square-\square)$ and placebo (O- - O). All treatments were given at zero time.

Atropine and adrenaline, in the doses used, caused greater responses than salmefamol at 20,80 and 120 $\min$. At $240 \mathrm{~min}$, however, the response to salmefamol had persisted and the mean value for the increase in $\mathrm{FEV}_{1}$ was greater than that following atropine by more than twice the standard error of the difference of the means at this time (Table 2). This difference is statistically significant at the $5 \%$ level. The difference between salmefamol and adrenaline at $\mathbf{2 4 0} \mathrm{min}$ is not statistically significant.

The pre-treatment values of $\mathrm{FEV}_{1}$ on the first day of the trial (Table 1) cover a wide range. Because of this it was thought possible that a different picture might emerge if changes in $\mathrm{FEV}_{1}$ were expressed as a percentage of the pre-treatment values rather than in absolute terms. However, analysis of these percentages revealed little alteration in the patterns of response.

The mean increase in FVC resulting from the different treatments is given in Table 3. At all times salmefamol showed a larger increase than occurred with the placebo. Adrenaline and atropine gave higher values up to $120 \mathrm{~min}$ but the effect of these drugs on FVC had declined by $240 \mathrm{~min}$. Although the effect of salmefamol on FVC at 240 min was greater than that of the other active drugs, the differences did not reach statistical significance. Table 3 shows 
TABLE 3. Mean increases in FVC (ml BTPS) over pretreatment values

\begin{tabular}{lrccr}
\hline & \multicolumn{4}{c}{ Time after treatment (min) } \\
\cline { 2 - 5 } \multicolumn{1}{c}{ Drug } & 20 & 80 & 120 & 240 \\
\hline Placebo aerosol & 52 & 134 & 150 & 63 \\
Salmefamol aerosol & 130 & 203 & 231 & 200 \\
Adrenaline s.c. & 269 & 368 & 300 & 179 \\
Atropine s.c. & 290 & 365 & 353 & 117 \\
$\begin{array}{l}\text { Standard error of the } \\
\quad \text { difference between }\end{array}$ & & & & \\
two drug means & $62 \cdot 5$ & $67 \cdot 2$ & $62 \cdot 6$ & $63 \cdot 2$ \\
\hline
\end{tabular}

The difference between two drug means is significant at (approximately) the $5 \%$ level when the observed difference between the means is greater than twice the standard error of the difference.

the placebo to have had a pronounced effect on FVC at 80 and $120 \mathrm{~min}$.

The analysis of the latin square showed that treatment sequence did not affect the average response of $\mathrm{FEV}_{1}$ or FVC. No carry over of the effect of any drug to the next day was detected.

No side effects were reported, or noticed after inhalation of either aerosol.

\section{Discussion and conclusions}

This study has demonstrated clearly that salmefamol produces bronchodilatation in man. Examination of the $\mathrm{FEV}_{1}$ curve (Fig. 2) reveals a consistent and prolonged effect after salmefamol lasting until the end of the study (4 hr). The statistical analysis has produced no evidence that salmefamol affected the next day's pre-treatment FEV $_{1}$. These facts would suggest that it is effective for between 4 and $24 \mathrm{hr}$. The nature of this trial did not allow precise determination of the end-point. The clinical value of this new bronchodilator may lie in its long action, a property similar to that of salbutamol; it will therefore be important to compare its potency and duration of action directly with those of salbutamol over a longer time period. It will be of practical value to assess the effect of different doses of this new drug. In addition, it will be important to monitor the effects upon heart rate and blood pressure to see whether the specificity for $\beta_{2}$ adrenergic receptors shown in animals is also applicable in man.

\section{Acknowledgments}

We thank Miss A. Gregor, Mrs L. Scott, Miss M. Cursiter and Mrs M. Gorman for skilled technical assistance, and are grateful to Professor J. W. Crofton and Dr A. C. Douglas for allowing us to study those of the patients who were under their care.

D.B. was in receipt of a research Fellowship from Allen and Hanburys Limited.

\section{References}

Armitage, P. (1971a) In: Statistical Methods in Medical Research, p. 288. Blackwell Scientific Publications, Oxford and Edinburgh.

Armitage, P. (1971b) In: Statistical Methods in Medical Research, p. 239. Blackwell Scientific Publications, Oxford and Edinburgh.

Brittain, R.T. \& Poynter, D. (1970) Personal communication.

Choo-Kang, J.F.J., Simpson, W.T. \& Grant, I.W.B. (1969) Controlled comparison of the bronchodilator effects of three $\beta$-adrenergic stimulant drugs administered by inhalation to patients with asthma. British Medical Journal, 2, 287.

CoTES, J.E. (1968) In: Lung Function, 2nd edn, p. 345 Blackwell Scientific Publications, Oxford and Edinburgh.

Crompton, G.K. (1968) A comparison of responses to bronchodilator drugs in chronic bronchitis and chroni asthma. Thorax, 23, 46.

Cullum, V.A., FARMer, J.B., JACK, D. \& Levy, G.P. (1969 Salbutamol: a new, selective $\beta$-adrenoceptive recepto옹 stimulant. British Journal of Pharmacology, 35, 141.

Freedman, S. \& Prowse, K. (1966) How many blows make an FEV $_{1 \cdot 0}$ ? Lancet, ii, 618.

Hartley, D., JACK, D., Lunts, L.H.C. \& Ritchie, A.C (1968) New class of selective stimulants of $\beta$-adrenergic receptors. Nature (London), 219, 861.

KENNEDY, M.C.S. \& SimPSON, W.T. (1969) Human pharmacological and clinical studies on salbutamol: a specific beta- adrenergic bronchodilator. British Journal of Diseases of the Chest, 63, 165.

Lands, A.M., Arnolf, A., McAuliff, J.P., Luduena, F.P. \& Brown, T.G. (1967) Differentiation of receptor systems activated by sympathomimetic amines. Nature (London), 214, 597.

McKerrow, C.B., McDermott, M. \& Gilson, J.C. (1960) A spirometer for measuring the forced expiratory volume with a single calibrating device. Lancet, i, 149.

Oldham, P. \& Hughes, D.T.D. (1972) Analysis of the results of bronchodilator trials. Bulletin de Physio-pathologie Respiratoire (Nancy), 8, 693. 